\title{
InefFicient Trade PatTerns: Excessive Trade, Cross-Hauling, AND DUMPING
}

by

Benjamin Eden

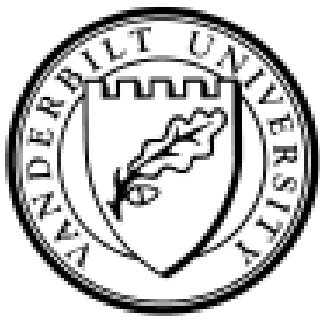

Working Paper No. 05-W03

February 2005

\section{DEPARTMENT OF ECONOMICS VANDERBILT UNIVERSITY \\ NASHVILLE, TN 37235}

www.vanderbilt.edu/econ 
INEFFICIENT TRADE PATTERNS: EXCESSIVE TRADE, CROSS-HAULING AND DUMPING

Benjamin Eden ${ }^{1}$

Vanderbilt University and The University of Haifa

February 2005

Mailing address: Economics, VU station B \#351819

2301 Vanderbilt Place, Nashville, TN 37235-1819

E-mail: ben.edenevanderbilt.edu

LEL Classification: F10

1 I would like to thank Rick Bond and Bob Driskill for very useful comments and discussions. 
INEFFICIENT TRADE PATTERNS: EXCESSIVE TRADE, CROSS-HAULING AND DUMPING

\begin{abstract}
I study an example of a competitive environment in which trade occurs in a sequential manner. In this example, a country with a stable demand may suffer from trade with a country with unstable demand, there may be too much trade, a country may import and export the same good in the same period (cross-hauling) and dumping may occur. The assumption about the timing of delivery is critical for our results. When delivery occurs before trade (delivery to stocks) trade improves welfare, there is dumping but no cross-hauling. When delivery occurs after trade (delivery to order), trade may reduce welfare, cross-hauling may occur but dumping does not occur.
\end{abstract}


1. INTRODUCTION

This paper examines the gains from international trade question and some puzzling trade patterns and pricing practices. For this purpose I study an example of a competitive environment in which trade occurs in a sequential manner. In this example, a stable demand country suffers from trade with an unstable demand country, there may be too much trade, a country may export and import the same good in the same period (crosshauling) and a country may export at a price that is lower than the price it charges at home (dumping).

The timing of delivery is important. When delivery occurs ex-ante before the arrival of buyers (delivery to stocks as in food items delivered to supermarkets) trade improves welfare, there is dumping but no cross-hauling. When delivery occurs ex-post (delivery to order as in internet trading), trade may reduce welfare, cross-hauling may occur but dumping does not occur. The analysis may thus shed light on the change in trade patterns that may occur as a result of the more complete integration achieved by internet trading and delivery to order.

Taking an explicit account of transportation costs is necessary for getting a unique equilibrium. It is shown that small transportation costs equilibrium may be different from the zero transportation cost equilibrium that minimizes the expected volume of trade.

The example used here builds on the work of prescott (1975), Butters (1977), Eden (1990) and Dana (1998) and applies it to issues in 
international trade. ${ }^{2}$ Roughly speaking, in this literature increasing the uncertainty about demand is "bad" from the social point of view because it leads to more price dispersion and lower average capacity utilization (fraction of output that is actually sold). A country with a relatively stable demand may therefore suffer from trade if as a result of trade there is an increase in price dispersion and a decrease in average capacity utilization. This may occur in the full integration, delivery to order case.

Dumping may occur in the segmented markets, delivery to stock case. The seller in the unstable demand country may export at a lower price because average capacity utilization is higher in the more stable demand country and therefore a lower price is required to cover marginal cost.

Cross-hauling and excess trade may occur in the fully integrated, delivery to order case because in this case buyers are treated symmetrically and typically some buyers from each country will arrive early and buy at a cheap price and some buyers from each country will arrive late and buy at a higher price.

The model has elements in common with Newbery and Stiglitz (1984). In both models trade in a single good arises as a result of uncertainty about demand (or supply) and markets are incomplete. But there are important differences. In Newbery and Stiglitz there is a single market clearing price in each period and capacity is always fully utilized. In

2 The model in Eden (1990) does not assume price rigidity while the models in Prescott (1975) and Dana (1998) assume price rigidity. This difference is important for some welfare analysis. See the discussion in Eden (2005, chapter 14). 
their model fluctuations in prices provide insurance to farmers against bad crops and are therefore "good" from the social point of view. Trade in their model may reduce welfare because it smoothes prices. In our model price dispersion is "bad" from the social point of view and trade may reduce welfare if it increases the dispersion in prices.

The model has some elements in common with the modern theory of cyclical dumping initiated by Ethier (1982). As in the peak-load-pricing model of Williamson (1966), the competitive price in Ethier's model is equal to the short run marginal cost when demand is low and capacity is not fully utilized. Ethier demonstrates that firms with high fixed cost due to labor contracts that promise secure employment may sell below average cost in downturns. In his model there is a single price that clears the international market (for steel in his example) and therefore the accusation of dumping will not be supported if the same period home price is used to define the "fair price". In our model a seller may export at a lower price than the same period home price and therefore an accusation of dumping may be supported even when there are enough data to compute the same period home price.

Our model is also related to the Cournot type model considered by Brander (1981) and Brander and Krugman (1983). In their model there is a single firm in each country that delivers its output to two markets: the home and the foreign market. The firm takes the quantities delivered to the two markets by the other firm as given and chooses quantities to maximize profits. Cross-hauling and reciprocal dumping may occur and if transportation costs are high, trade may reduce welfare. In our model the environment is competitive and firms take prices as given. Crosshauling in our model occurs only in the delivery to order case while the 
Brander and Krugman game suggests segmented markets and delivery to stock. Our countries are not symmetric and it is essential for our results that demand in one country is less stable than the demand in the other country.

2. THE MODEL

I assume a single period economy, two countries ( 1 and 2 ), two goods ( $\mathrm{X}$ and $\mathrm{Y}$ with lower case letters denoting quantities) and two states of nature ( 1 and 2 ) that occur with equal probabilities. In each country there are two types of agents: Sellers (producers) and buyers. All agents are risk neutral and get a large endowment of good $\mathrm{Y}$. The number of sellers in each country is equal to the number of buyers and is normalized to 1 .

All the sellers (in both countries) are the same. Sellers are risk neutral and derive utility only from $Y$. Their utility function is: $\mathrm{u}(\mathrm{x}, \mathrm{y})=\mathrm{y}$. They can use their endowment of $\mathrm{Y}$ to produce $\mathrm{x}$. The cost of producing $\mathrm{x}$ units of $\mathrm{x}$ is $\mathrm{C}(\mathrm{x})=(1 / 2) x^{2}$ units of $\mathrm{Y}$. Production must occur before the beginning of trade.

Buyers are risk neutral and differ in the probability that they want to consume $\mathrm{x}$. The buyers in country 1 always want to consume $\mathrm{x}$ while the buyers in country 2 want to consume $x$ only in state 2 . Country 1 's buyer utility function is: $\mathrm{u}(\mathrm{x}, \mathrm{y})=\mathrm{y}+\mathrm{U}(\mathrm{x})$, where $\mathrm{U}(\mathrm{x})=\ln (\mathrm{x})$. The buyers in country 2 have a random utility function: $\mathrm{u}(\mathrm{x}, \mathrm{y})=\mathrm{y}$ in state of nature 1 and $\mathrm{u}(\mathrm{x}, \mathrm{y})=\mathrm{y}+\mathrm{u}(\mathrm{x})$ in state 2 . A buyer who wants to consume and face the price p, solves $\max _{x} U(x)$ - px. The first order condition for this problem is: 
$\mathrm{U}^{\prime}(\mathrm{x})=1 / \mathrm{x}=\mathrm{p}$. The demand function of an individual who wants to consume is thus: $D(p)=1 / p$. A seller who can sell with probability $q$ at the price $p$ solves: $\max _{x} q p x-c(x)$. The first order condition for an interior solution to this problem is: $C^{\prime}(x)=x=q p$.

Under autarky there is no uncertainty about demand in country 1 , the probability of making a sale is $q=1$ and therefore in equilibrium:

$$
\mathrm{U}^{\prime}(\mathrm{x})=\mathrm{C}^{\prime}(\mathrm{x})=\mathrm{p}
$$

The solution to $(1)$ is: $x=p=1$. Profits in the autarkic equilibrium are: $\mathrm{px}-1 / 2 \mathrm{x}^{2}=0.5$. The buyer's utility is: $\ln (\mathrm{x})+\bar{y}-\mathrm{xp}=\ln (\mathrm{x})+\bar{y}-1$, where $\bar{y}$ is the buyer's endowment of $\mathrm{Y}$. I omit $\bar{y}$ and write the buyer's utility as: $\ln (\mathrm{x})-1=-1$. Welfare in country 1 is measured by the sum of the agents' objective functions. It is: $0.5-1=-0.5$.

In country 2 demand (under autarky) is positive only in state 2 , the probability of making a sale is $q=1 / 2$ and therefore in equilibrium: $C^{\prime}(x)=1 / 2 p$. The equilibrium condition for country 2 is thus: $\mathrm{U}^{\prime}(\mathrm{x})=2 \mathrm{C}^{\prime}(\mathrm{x})=\mathrm{p}$. The solution to these equations is: $\mathrm{x}=0.707$ and $\mathrm{p}=1.414$. Profits are: $(1 / 2)\left(\mathrm{px}-\mathrm{x}^{2}\right)=0.25$. The buyer's utility is: $(1 / 2)[\ln (1 / p)-1]=-0.673$. Welfare is: $0.25-0.673=-0.423$. On average only $1 / 2$ of the quantity produced in country 2 is sold and therefore average capacity utilization in country 2 is $1 / 2$.

Figure 1 illustrates the equilibrium price in both countries under autarky. The price in country 2 is higher and the quantity produced is lower because average capacity utilization in country 2 is lower. 


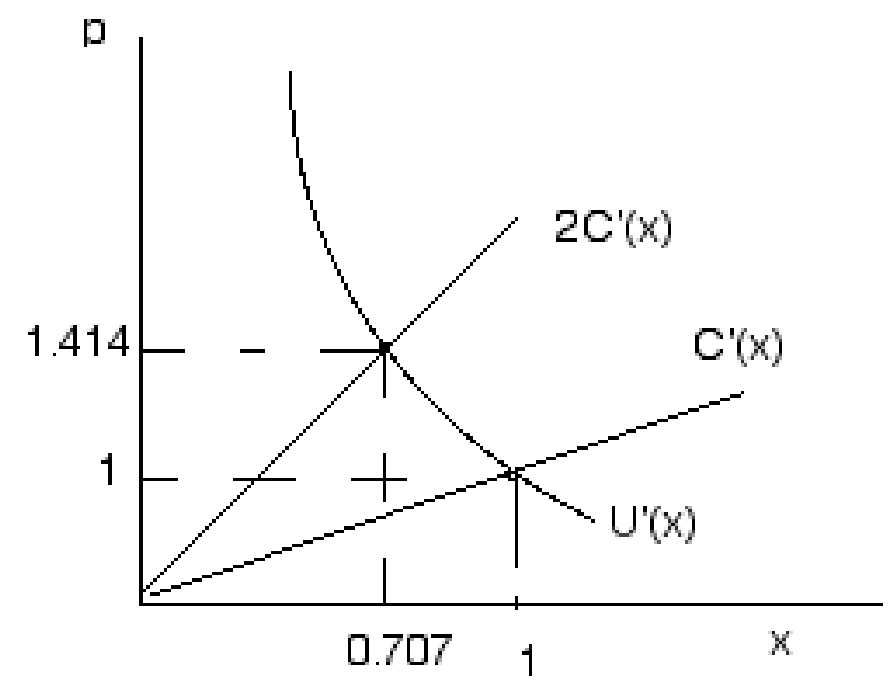

Figure 1: Equilibrium Under Autarky

\begin{abstract}
Since under autarky there is a difference between the marginal costs of the two sellers, there is an incentive for trade between the two countries. I now allow for international trade under two alternative assumptions about trade technology.
\end{abstract}

\title{
2.1 DELIVERY TO STOCKS (SEGMENTED MARKETS)
}

I start with the assumption that merchandise must be displayed on location before the beginning of trade. We may think of food products displayed in a supermarket for example. I assume that it costs $\tau$ units of $\mathrm{Y}$ to transport a unit of $\mathrm{X}$ from one country to another. I use the following notation:

$\mathrm{x}_{\mathrm{j} m}=$ supply to counrty $\mathrm{j}$ by a seller who resides in country $\mathrm{m}$ ( seller $\mathrm{m})$; $p_{j}=$ the price in country $j$. 


$$
\begin{aligned}
& \text { Seller } m \text { takes the prices } p_{j} \text { as given and chooses the quantities } \\
& \mathrm{x}_{j \mathrm{~m}} \text { to maximize his expected profits: } \\
& \text { (2) } p_{1} x_{1 m}+(1 / 2) p_{2} x_{2 m}-(1 / 2)\left(x_{1 m}+x_{2 m}\right)^{2}-\tau \sum_{j \neq m} x_{j m}
\end{aligned}
$$

Note that seller m pays the transportation cost only for units supplied to country $j \neq m$. Note also that in this delivery to stock case transportation costs are paid regardless of whether the unit is sold or not.

To write the first order conditions for (2) I use the indicator function: $I(j \neq m)=1$ if $j \neq m$ and zero otherwise. As before $q_{j}$ is the probability of making a sale in country $j\left(q_{1}=1\right.$ and $\left.q_{2}=0.5\right)$. The first order conditions are:

$$
C^{\prime}\left(x_{1 m}+x_{2 m}\right)+I(j \neq m) \tau \geq q_{j} p_{j} \text { with equality if } x_{j m}>0
$$

Condition (3) says that the marginal cost of production, $\mathrm{C}^{\prime}($ ), plus the transportation cost must be greater than the expected revenue if the supply is zero and must equal to it if the supply is strictly positive. Market clearing requires:

$$
x_{j 1}+x_{j 2}=\mathrm{D}\left(\mathrm{p}_{\mathrm{j}}\right) \text { for } \mathrm{j}=1,2 \text {. }
$$

Note that (3) and (4) is a system of six equations in six unknowns: $\mathrm{x}_{11}, \mathrm{x}_{12}, \mathrm{x}_{21}, \mathrm{x}_{22}, \mathrm{p}_{1}, \mathrm{p}_{2}$. 
Solution: Since under autarky the marginal cost of seller 2 is lower than the marginal cost of seller 1 we expect that seller 1 will increase production and export it to country 1. This will reduce price and production in country 1 and will work in the direction of lowering the difference in the marginal cost. I therefore start by guessing a solution in which seller 2 supplies to both countries while seller 1 supplies only to his home country: $\mathrm{x}_{12}>0, \mathrm{x}_{22}>0, \mathrm{x}_{11}>0$ and $\mathrm{x}_{21}=0.3$ I use $P$ for the marginal cost of seller 2 . Since under the proposed solution seller 2 supplies to both countries we must have:

$$
P=p_{1}-\tau=(1 / 2) p_{2}
$$

We can now express prices in each country in terms of $P$ :

$$
\mathrm{p}_{1}=\mathrm{P}+\tau \text { and } \mathrm{p}_{2}=2 \mathrm{P}
$$

I use $x_{1}=x_{11}$ to denote the supply of seller 1 and $x_{2}=x_{12}+x_{22}$ to denote the supply of seller 2 . Using $\mathrm{C}(\mathrm{x})=(1 / 2) x^{2}$, leads to:

3 An equilibrium in which seller 1 exports the good can be ruled out by the following argument. If country 1 exports, the marginal cost in country 2 must be higher than in country 1 and total supply to country 2 (home production plus import) must be higher in country 2. This says that the price in country 2 must be lower than in country 1 . But then sellers in country 1 have no incentive to export at a lower price to a country that the probability of making a sale is relatively low. It is also possible to rule out an equilibrium in which both sellers export the good. 


$$
C^{\prime}\left(x_{1}\right)=x_{1}=P+\tau \text { and } C^{\prime}\left(x_{2}\right)=x_{2}=P \text {. }
$$

Using (6) and $e=x_{12}$ to denote export by seller 2 , the market clearing conditions are:

$$
\mathrm{x}_{1}+\mathrm{e}=\mathrm{D}(\mathrm{P}+\tau)=1 /(\mathrm{P}+\tau) \text { and } \mathrm{x}_{2}-\mathrm{e}=\mathrm{D}(2 \mathrm{P})=1 / 2 \mathrm{P} \text {. }
$$

We now have four unknowns $\left(\mathrm{x}_{1}, \mathrm{x}_{2}, \mathrm{e}, \mathrm{P}\right)$ with four equations (7) and (8). After some substitutions we arrive at the following equation for $P$ :

$$
F(P)=2 P^{2}+3 P \tau+\tau^{2}-(\tau / 2 P)-3 / 2=0
$$

The function $F(P)$ is strictly increasing in $P$ and $F(P)<0$ for small $\mathrm{P}$ and $\mathrm{F}(\mathrm{P})>0$ for large $\mathrm{P}$. Therefore, there exists a unique solution to (9).

Table 1 calculates the equilibrium magnitudes for three levels of transportation costs: $0,0.1$ and prohibitively large (the autarkic case discussed above). For the sake of comparison with subsequent cases I use $e_{s}$ to denote the amount of export in state $s$ and $A v=\left(\left|e_{1}\right|+\left|e_{2}\right|\right) / 2$ to denote the average amount of trade. I start from the autarkic case in which the marginal cost of seller 2 is lower than the marginal cost of seller 1 . We then lower transportation costs and this works to reduce the difference between the marginal costs by increasing the marginal cost of seller 2 and reducing the marginal cost of seller 1 . As a result the price in country 1 goes down and the price in country 2 goes up. 
Note that since $\mathrm{p}_{2} \leq 2 \mathrm{p}_{1}$, seller 1 has no incentive to export to country 2 and the above solution is indeed an equilibrium solution.

Table $1^{*}:$ A delivery to stock case of international trade

\begin{tabular}{|l|l|l|l|l|l|l|l|l|}
\hline$\tau$ & $\mathrm{P}$ & $\mathrm{p}_{1}$ & $\mathrm{p}_{2}$ & $\mathrm{x}_{1}$ & $\mathrm{x}_{2}$ & $\mathrm{e}_{1}$ & $\mathrm{e}_{2}$ & $\mathrm{Av}$ \\
\hline 0 & 0.866 & 0.866 & 1.732 & 0.866 & 0.866 & 0.289 & 0.289 & 0.289 \\
\hline 0.1 & 0.809 & 0.909 & 1.618 & 0.909 & 0.809 & 0.191 & 0.191 & 0.191 \\
\hline prohibitive & 0.707 & 1 & 1.414 & 1 & 0.707 & 0 & 0 & 0 \\
\hline
\end{tabular}

* The first column is per unit transportation cost $(\tau)$, the second is the marginal cost for seller $2(P)$, we then have the prices in countries 1 and $2\left(p_{1}, p_{2}\right)$, the amount produced by sellers 1 and $2\left(x_{1}, x_{2}\right)$, the amount exported by seller 2 in states 1 and $2\left(e_{1}, e_{2}\right)$ and the average amount of trade (Av).

Figure 2 illustrates the equilibrium magnitudes for the case $\tau=0.1$. We see that seller 2 produces 0.809 units and allocate 0.618 units to his own country while the rest $(0.191)$ is exported to country 1. Seller 1 produces 0.909 units and allocates all of it to his home country. The total amount consumed by the buyers in country 1 is the sum of the home production and export. 


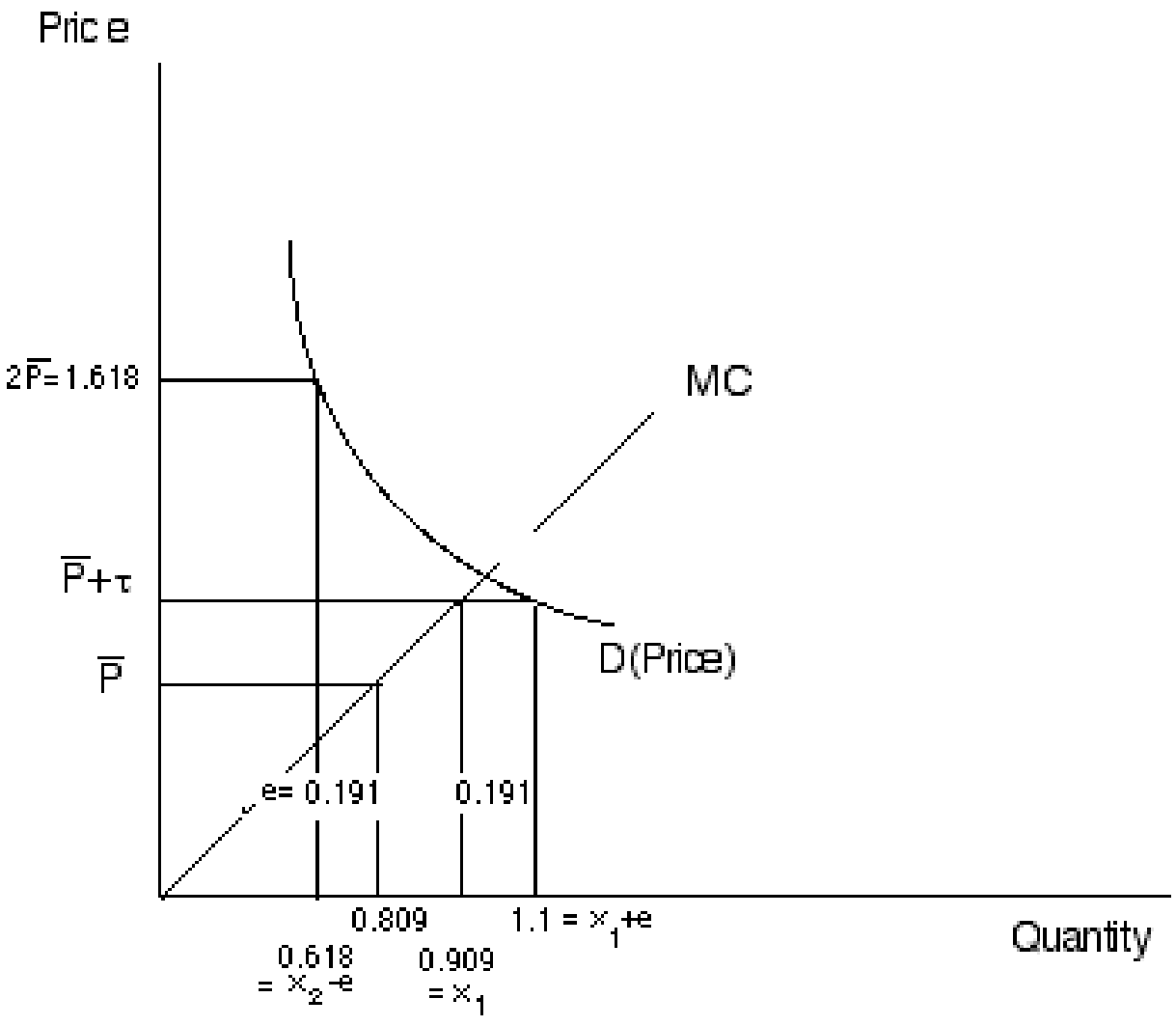

Figure 2: Equilibrium magnitudes when $\tau=0.1$ and delivery is to stocks.

Table 2 calculates the level of the objective function of each of the four agents and their sum in each country. Not surprisingly, the profits of seller 1 go down with the decline in transportation costs while the profits of seller 2 go up. But total welfare goes up in each country as a result of lowering transportation costs. 
Table $2^{*}$ : Welfare calculations for the examples in Table 1

\begin{tabular}{|l|l|l|l|l|l|l|}
\hline$\tau$ & seller 1 & seller 2 & buyer 1 & buyer 2 & welfare 1 & welfare 2 \\
\hline 0 & 0.375 & 0.375 & -0.856 & -0.775 & -0.481 & -0.400 \\
\hline 0.1 & 0.413 & 0.327 & -0.905 & -0.741 & -0.491 & -0.413 \\
\hline prohibitive & 0.5 & 0.25 & -1 & -0.673 & -0.5 & -0.423 \\
\hline
\end{tabular}

* The first column is the per unit transportation costs $(\tau)$. We then have the expected profits of the seller in country 1 and the seller in country 2. The expected utility of the buyers follows. We then compute the sum of the seller's expected profits and the buyer's expected utility in each country.

Note that seller 2 exports at a price that is lower than the price in his country. The intuition is clear: capacity utilization (fraction of output sold) is higher in country 1 and therefore the price is lower in country 1. Seller 2 may therefore be accused of dumping. I now turn to a brief discussion of this issue.

Dumping: A seller may be accused of dumping whenever he exports at a price that is less than the "fair price". According to Blonigen (2003) the "preferred" method of calculating the "fair price" is the price of the product before it leaves the factory in the home country. But since this is inherently unobserved, final consumer prices are used after various adjustments. When the investigated foreign firm does not have "sufficient" sales of the product in its own market, sales in a third country are used. If there are no "sufficient" sales to a third country, estimated average cost is used. 
In our model (Table 1) exports in the high demand state occurs at a lower price then in the home country and therefore seller 2 may be accused of dumping. In the low demand state, a high price is quoted in country 2 but there are no transactions at this price. Therefore in the low demand state the accusation of dumping may not be supported. In the Appendix I work out an example in which there are two strictly positive realizations of demand in country 2. In this example, there are always transactions in country 2 but in the low demand period the export price is the same (after taking transportation costs into account) as the price at home. Only in the high demand state an accusation of dumping can be supported. An accusation of dumping can also be supported if an average over time is used to calculate the "fair price" or average quoted prices (rather than actual transaction prices) is used.

As was said in the introduction, our model has common elements with Ethier (1982). There are some important differences however. Ethier uses Williamson's peak-load pricing model in which there is a single price that clears the world market (for steel in his example). Therefore, in Ethier's model an accusation of dumping will not be supported if the "fair price" is defined as the same-period price at the home country. As in our model an accusation of dumping may be supported if an average over time is used. But unlike our model, in the Ethier's model export occurs at prices that are below average cost and therefore an accusation of dumping may be supported if the "fair price" is defined by average cost. Finally, in Ethier's model the cost of production is different across countries while in our model it is the distribution of the taste shock that is different. The analysis of dumping here is also 
different from the traditional price discrimination view in Viner (1923) because here sellers do not have monopoly power.

2.2 DELIVERY TO ORDER (FULL INTEGRATION)

I now relax the assumption that goods must be displayed on location and allow buyers to order the good on the internet. Buyers' orders arrive sequentially and delivery occurs at the end of the arrival process. Transportation costs are paid only if actual delivery takes place. As before production must occur ex-ante before the beginning of trade. Figure 3 illustrates the sequence of events.

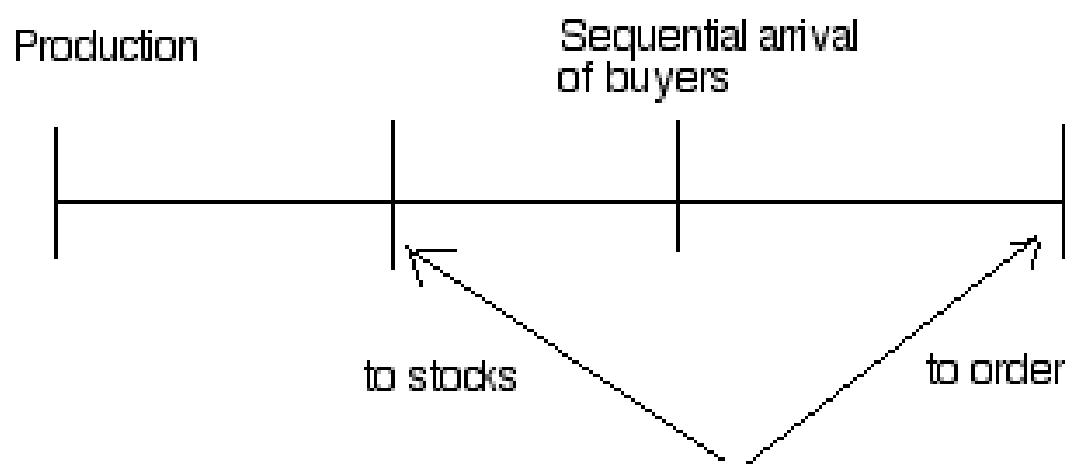

Delivery

Figure 3: Sequence of events under the delivery to stocks and delivery to order.

In the previous delivery to stocks case the buyers in country 1 bought at the low price and (in state 2) the buyers in country 2 bought at the high price. Here I treat all buyers symmetrically (as trade on 
the internet suggests) and assume that all buyers who want to consume have the same chance of buying at the lower price. This makes a big difference both for the welfare analysis and for the trade patterns that may emerge.

It makes a big difference for the welfare analysis because country 1 buyers lost their priority on buying at the low price and may now be forced to buy at the high price (in the high demand state). As a result buyer 1 may suffer from trade and since the profits of seller 1 goes down as well, country 1 may suffer from trade.

We can also have exotic trade patterns where country 2 exports and imports the same good at the same time. This occurs when country 1 supplies the good at a low price and country 2 supplies it at both prices as in the previous delivery to stocks case. But unlike the previous case, buyers from country 1 may not be able to buy at the cheap price. In state 2, when everyone wants to consume, only half of the buyers in country 1 can make a buy at the low price and the other half is forced to buy at the high price. Since sellers in country 1 supply relatively more at the low price and since the number of buyers who buy at the low price (in state 2 ) is the same in both countries, country 2 imports at the low price. Since only the sellers in country 2 supply at the high price and since some buyers from country 1 buy at the high price, country 2 exports at the high price. Thus, country 2 imports and exports the same good in the same period. This is sometimes called cross-hauling.

To get cross-hauling we need an equilibrium in which the two sellers supplies is asymmetric: Seller 1 supplies only at the low price while seller 2 supplies at both prices. It will be shown that such an 
asymmetric equilibrium emerges when there are transportation costs. But this asymmetric equilibrium does not economize on transportation costs. To show this we start by describing the symmetric equilibrium.

Symmetric equilibrium: I start with the case in which there are no transportation costs and consider a fully integrated, free trade world economy. Trade occurs sequentially in the following way. Buyers who want to consume form a line. After forming the line the buyers arrive at the market place (go on the internet) one by one in a process that does not take real time (it occurs in meta time). Upon arrival buyers see all price offers and the location of the seller. They choose to buy at the cheapest available offer after taking transportation costs into account. In this fully integrated world economy either 1 buyer will arrive or 2 buyers will arrive. From the sellers' point of view a first batch (of 1 buyer) arrives with certainty and after it completes trade a second batch (of 1 buyer) may arrive (with probability $1 / 2$ ). The buyers' composition in each batch represents the worldwide composition of buyers who want to consume. In state 1 , only the first batch arrives and all of the buyers in this batch are from country 1 . In state 2 two batches arrive and in each batch half of the buyers are from country 1 and half are from country 2. Sellers are price-takers and expect to be able to sell to the first batch at the price $p_{1}$ and to the second batch at the price $p_{2}$ if it arrives. Seller m makes a contingent plan that specifies the amount, $k_{i m}$, that he will sell to batch $i$ if it arrives.

It is convenient to talk about two markets. The first market opens with certainty at the price $p_{1}$ and the second market opens with probability $1 / 2$ (if type 2 buyers want to consume) at the price $p_{2}$. 
Before the first market was in country 1 and the second in country 2 . Here the markets are not location specific and the buyers in each market may come (in state 2) from both countries.

Seller m chooses the supply to market $i, k_{i m}$, by solving:

$$
\max _{k_{1 m}, k_{2 m}} p_{1} k_{1 m}+(1 / 2) p_{2} k_{2 m}-C\left(k_{1 m}+k_{2 m}\right)
$$

The first order conditions that an interior solution to (10) must satisfy are:

$$
p_{1}=(1 / 2) p_{2}=C^{\prime}\left(k_{1 m}+k_{2 m}\right)=k_{1 m}+k_{2 m} .
$$

Equilibrium requires in addition to the first order conditions (11) the market clearing conditions:

$$
k_{11}+k_{12}=D\left(p_{1}\right)=1 / p_{1} \text { and } k_{21}+k_{22}=D\left(p_{2}\right)=1 / p_{2} \cdot
$$

In the symmetric case: $k_{i 1}=k_{i 2}=k_{i}$. In state 1 seller 2 exports $\mathrm{e}_{1}=\mathrm{k}_{1}$ units to country 1 . In state 2 the demand in each country is the same and there is no trade across countries. The average amount of trade is thus: $\operatorname{Av}=(1 / 2) k_{1}$. The symmetric solution to (11) and (12) is in the first row of Table 3. The second row is the autarkic case that is brought here from the previous discussion to facilitate comparison. As was said before, in the autarkic case there is a difference between the marginal costs of the two sellers. This difference is eliminated when transportation costs drop to zero. The supply (per seller) to market 1 goes up (from 0.5 to 0.577 ) and the supply to market 2 goes down (from 
0.354 to 0.289 ). Thus relative to free trade there is too much production under autarky in country 1 and too little production in country 2. There is too much output allocated to market 2 and too little to market 1 .

Table 3: Costless deliver to order and autarky

\begin{tabular}{|l|l|l|l|l|l|l|l|l|}
\hline$\tau$ & $\mathrm{P}$ & $\mathrm{p}_{1}$ & $\mathrm{p}_{2}$ & $\mathrm{k}_{1}$ & $\mathrm{k}_{2}$ & $\mathrm{e}_{1}$ & $\mathrm{e}_{2}$ & $\mathrm{Av}$ \\
\hline 0 & 0.866 & 0.866 & 1.732 & 0.577 & 0.289 & 0.577 & 0 & 0.289 \\
\hline prohibitive & 0.707 & 1 & 1.414 & 0.5 & 0.354 & 0 & 0 & 0 \\
\hline
\end{tabular}

Expected profits per seller are: $p_{1} k_{1}+(1 / 2) p_{2} k_{2}-(1 / 2)\left(k_{1}+k_{2}\right)^{2}=0.375$. The fraction of revenues obtained in market 1 when both markets open is: $\theta=\frac{p_{1} k_{1}}{p_{1} k_{1}+p_{2} k_{2}}=1 / 2$. Since each buyer spends a unit of $\mathrm{Y}, \theta=1 / 2$ is the probability that this unit will buy in market 1 when both markets open. The expected utility of buyer 1 is therefore:

$$
(1 / 2) \ln \left(1 / p_{1}\right)+(1 / 2)\left[\theta \ln \left(1 / p_{1}\right)+(1-\theta) \ln \left(1 / p_{2}\right)\right]-1=-1.029
$$

Relative to autarky, the welfare of both buyers and sellers in country 1 is lower.

The expected utility of country 2's buyer is:

$$
(1 / 2)\left[\theta \ln \left(1 / p_{1}\right)+(1-\theta) \ln \left(1 / p_{2}\right)-1\right]=-0.601
$$


Relative to autarky, both the buyer and the seller in country 2 are better off. Table 4 summarizes the welfare calculations.

Table $4^{*}$ : Welfare calculations for the allocations in Table 3

\begin{tabular}{|l|l|l|l|l|l|l|}
\hline$\tau$ & seller 1 & seller 2 & buyer 1 & buyer 2 & welfare 1 & welfare 2 \\
\hline 0 & 0.375 & 0.375 & -1.029 & -0.601 & -0.654 & -0.226 \\
\hline prohibitive & 0.5 & 0.25 & -1 & -0.673 & -0.5 & -0.423 \\
\hline
\end{tabular}

* The first column is the transportation cost. Then we have the expected profits of the seller in country 1 and country 2. A measure of the expected utility of the buyer in each country follows. The last two columns compute the welfare in each country defined as the sum of the seller's expected profits and the buyer's expected utility.

The standard result is that some individuals in every country gain from trade and by appropriate transfers we can get a Pareto improvement by moving from autarky to trade. Here all the agents in country 1 loose from trade and all the agents in country 2 gain from trade.

To build some intuition note that under autarky (and in the delivery to stocks case) average capacity utilization (fraction of output sold) in country 1 is 1 and in country 2 is $1 / 2$. In the fully integrated world economy average capacity utilization is: $1 / 2+(1 / 2) k_{1} /\left(k_{1}+k_{2}\right)=0.833$. Thus as a result of trade average capacity utilization went down in country 1 and up in country 2. Roughly speaking we may think of average capacity utilization as a measure of markets performance. Country 1 starts with a perfectly efficient market in which everything that is produced is sold. When it opens to trade only a fraction of what was produced is sold and therefore welfare goes down. 
On a deeper level the reason for the surprising welfare result is in incomplete markets. Unlike Newbery and Stiglitz (1984), here agents are risk neutral so that there is no lack of insurance markets. But we miss ex-ante markets for allocating capacity. ${ }^{4}$

The above analysis assumes a symmetric equilibrium in which both sellers allocate identical amounts to the two hypothetical markets. Since sellers are indifferent to the way they allocate output across markets there are many other equilibria. 5 We now show that these other equilibria require a higher volume of trade relative to the symmetric case.

Claim 1: The symmetric equilibrium minimizes expected trade between the two countries.

Proof: Suppose seller 1 allocates $k_{11}=k_{1}+\varepsilon$ units to market 1 and $\mathrm{k}_{12}=\mathrm{k}_{2}-\varepsilon$ units to market 2 where $\mathrm{k}_{\mathrm{i}}$ is the symmetric equilibrium allocation. (Seller 2 allocates $\mathrm{k}_{21}=\mathrm{k}_{1}-\varepsilon$ units to market 1 and $\mathrm{k}_{22}=\mathrm{k}_{2}+\varepsilon$ units to market 2$)$. We assume $|\varepsilon| \leq \min \left(\mathrm{k}_{1}, \mathrm{k}_{2}\right)$ so that all the quantities supplied are positive. In the low demand state the buyers in country 1 consume the total supply to market 1 . Therefore in state 1 country 2 exports $k_{1}-\varepsilon$ units. Since each batch of buyers accurately

4 Here a complete Arrow-Debreu markets require that all agents meet prior to the choice of production and trade in two contingent commodities: one per state.

5 Technically, the equilibrium conditions (11) and (12) determine only the total supplies to each of the two markets (or the average supply per seller $k_{i}$ ) and not the individual supplies $k_{i m}$. 
represents the composition of buyers who want to consume, in the high demand state an equal number of buyers from each country participate in each of the two markets. Therefore in the high demand state country 1 exports $\varepsilon$ units in the low price and imports $\varepsilon$ units at the high price. Trade in the high demand state is $2|\varepsilon|$ and expected trade over the two states is:

(15) $(1 / 2)\left(k_{1}-\varepsilon\right)+(1 / 2) 2|\varepsilon|=(1 / 2) k_{1}+|\varepsilon|-(1 / 2) \varepsilon$.

Expected trade is minimized at the symmetric equilibrium when $\varepsilon=0$.

I now introduce transportation costs to pin down the equilibrium solution and see whether the equilibrium outcome minimizes transportation costs.

Transportation costs: The introduction of transportation costs ruins the symmetric equilibrium. To see this point, note that the first market price clears the market in the low demand state. Since all the buyers in the low demand state reside in country 1 , transportation costs introduce a discrepancy between the first market price that country 1 buyers pay and the first market price that country 2 sellers get. But the price that country 1 buyers pay is the same as the price that country 1 sellers get. Therefore the first market price that sellers in country 1 get is higher and as a result they specialize in supplying to the first hypothetical market. Since buyers are treated symmetrically, this leads to exotic trade patterns. 
I now turn to describe the emerging asymmetric equilibrium in detail. I assume here that the buyer pays transportation costs of $\tau$ units of $Y$ per unit of $X$ if actual delivery takes place. It is also assumed that the buyer sees the location of the seller at the time he makes his order on the internet.

Seller $m$ assumes that he can sell to the first batch at the (net of transportation cost) price $\mathrm{p}_{1 \mathrm{~m}}$ and to the second batch (if it arrives) at the price $\mathrm{p}_{2 \mathrm{~m}}$. He chooses the quantities $\mathrm{k}_{\mathrm{im}}$ to maximize expected profits:

$$
\mathrm{p}_{1 \mathrm{~m}} \mathrm{k}_{1 \mathrm{~m}}+(1 / 2) \mathrm{p}_{2 \mathrm{~m}} \mathrm{k}_{2 \mathrm{~m}}-\mathrm{C}\left(\mathrm{k}_{1 \mathrm{~m}}+\mathrm{k}_{2 \mathrm{~m}}\right)
$$

The first order conditions for this problem are:

$$
C^{\prime}\left(k_{1 m}+k_{2 m}\right) \geq q_{i} p_{i m} \text { with equality if } k_{i m}>0
$$

In the low demand state, only the buyers in country 1 want to consume. For these buyers the relevant price is $\min \left(\mathrm{p}_{11}, \mathrm{p}_{12}+\tau\right)$ because if they import the good they must pay transportation costs. The clearing of the first market therefore requires:

$$
\mathrm{k}_{11}+\mathrm{k}_{12}=\mathrm{D}\left[\min \left(\mathrm{p}_{11}, \mathrm{p}_{12}+\tau\right)\right]
$$

In the high demand state there are exactly half buyers from each country who could not buy at the first market price and want to buy in the second market. The relevant price is different for the two type of buyers. It is: $\min \left(p_{21}, p_{22}+\tau\right)$ for buyers in country 1 and 
$\min \left(\mathrm{p}_{21}+\tau, \mathrm{p}_{22}\right)$ for buyers in country 2 . The clearing of the second market therefore requires:

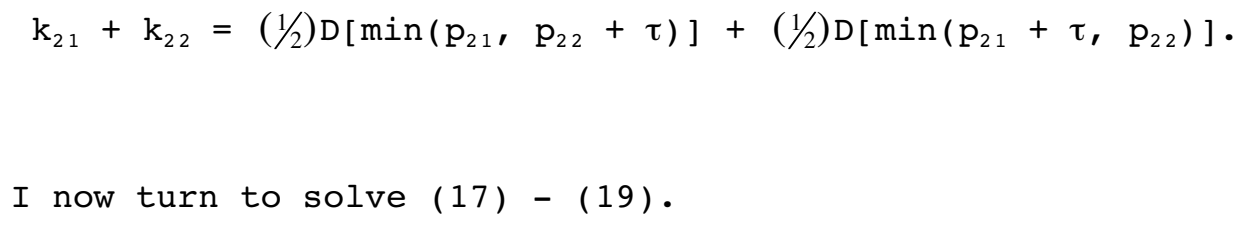

Solution: I proceed by guessing that only seller 2 supplies to market 2 $\left(k_{21}=0\right)$. I express equilibrium magnitudes as a function of the marginal cost of seller 2: P. Seller 1 quotes one price: $\mathrm{p}_{11}=\mathrm{P}+\tau$. Seller 2 quotes two prices: $\mathrm{p}_{12}=\mathrm{P}$ and $\mathrm{p}_{22}=2 \mathrm{P}$. We can now write $(17)-(19)$ as:

$$
\begin{gathered}
C^{\prime}\left(k_{12}+k_{22}\right)=k_{12}+k_{22}=P \\
C^{\prime}\left(k_{11}\right)=k_{11}=P+\tau \\
k_{11}+k_{12}=D(P+\tau)=1 /(P+\tau) \\
k_{22}=(1 / 2) D(2 P)+(1 / 2) D(2 P+\tau)=1 / 4 P+1 /(4 P+2 \tau)
\end{gathered}
$$

These are four equations in four unknowns: $\left(k_{11}, k_{12}, k_{22}, P\right)$. These equations lead to the following equation in P:

$$
(P+\tau)^{-1}+(4 P)^{-1}+(4 P+2 \tau)^{-1}=\tau+2 P .
$$

Note that since $\mathrm{p}_{22}+\tau=2 \mathrm{P}+\tau<2 \mathrm{p}_{11}=2(\mathrm{P}+\tau)$, the assumption 
$k_{21}=0$ is consistent with equilibrium.

To describe the equilibrium trade patterns, I use the following notation:

$\mathrm{e}_{1}=\mathrm{k}_{12}=$ export from country 2 in state $1 ;$

$e_{21}=(1 / 2)\left(1 / P_{11}\right)-k_{11}=$ export from country 2 in state 2 at the low price;

$e_{22}=(1 / 2)\left[1 /\left(P_{22}+\tau\right)\right]=$ export from country 2 in state 2 at the high price;

$\operatorname{Av}=\left(\left|e_{1}\right|+\left|e_{21}\right|+\left|e_{22}\right|\right) / 2=$ average volume of trade. When $e<0$ we have import rather than export.

Table 5 describes the equilibrium magnitudes for various $\tau$. When $\tau=0.1, P=0.804$ and seller's 1 first market price is: $\mathrm{p}_{11}=\mathrm{P}+\tau=0.904$. Seller 2 charges the first market price of $\mathrm{p}_{12}=\mathrm{P}=0.804$ and the second market price $\mathrm{P}_{22}=2 \mathrm{P}=1.609$. Seller 1 allocates all his output to the first market: $k_{11}=0.904$. Seller 2 produces 0.804 units and allocates $k_{12}=0.201$ to the first market and $k_{22}=0.603$ to the second market. In state 1 , seller 2 exports his allocation to market $1: e_{1}=k_{12}=0.201$. In state 2 , half of the buyers in market 1 are from country 1 . They spend $1 / 2$ a unit of $Y$ at the price $\mathrm{p}_{11}=0.904$. They thus buy $1 / 2(0.904)=0.553$ units. The rest of the supply of seller 1 is exported. Thus, $-e_{21}=0.904-0.553=0.351$. By assumption, half of the buyers in market 2 (in state 2) are from country 1. They spend $1 / 2$ a unit of $Y$ at the price $p_{22}+\tau=1.709$. They thus import $e_{22}=1 / 2(1.709)=0.293$ units. Thus, in state 2 country 2 exports at the high price and imports at the low price. 
Table $5^{*}$ : Costly delivery to order

\begin{tabular}{|l|l|l|l|l|l|l|l|l|l|l|}
\hline$\tau$ & $\mathrm{p}_{11}$ & $\mathrm{p}_{12}$ & $\mathrm{p}_{22}$ & $\mathrm{k}_{11}$ & $\mathrm{k}_{12}$ & $\mathrm{k}_{22}$ & $\mathrm{e}_{1}$ & $\mathrm{e}_{21}$ & $\mathrm{e}_{22}$ & $\mathrm{Av}$ \\
\hline$\tau \rightarrow 0$ & 0.866 & 0,866 & 1.732 & 0.866 & 0.289 & 0.577 & 0.289 & -0.289 & 0.289 & 0.433 \\
\hline 0.1 & 0.904 & 0.804 & 1.609 & 0.904 & 0.201 & 0.603 & 0.201 & -0.351 & 0.293 & 0.423 \\
\hline large & 1 & 0.707 & 1.414 & 1 & 0 & 0.707 & 0 & 0 & 0 & 0 \\
\hline
\end{tabular}

* The first column is the per unit transportation cost. We then have the producer prices: the first market price that seller 1 gets, the first market price that seller 2 gets and the second market price that seller 2 gets. The next three columns describe the allocation. Seller 1's supply to the first market and seller 2's supplies to the first and the second market. The next three columns describe country 2 's export (import with a negative sign). The export in state 1 at the low price, the import in state 2 at the low price and the export in state 2 at the high price. The last column is the average volume of trade.

Note that a decline in transportation costs leads to: (a) a decline in the ratio of the marginal costs $\mathrm{p}_{11} / \mathrm{p}_{12}$; this ratio approaches unity as $\tau$ approaches zero; and (b) an increase in the average volume of trade. Note also that when $\tau \rightarrow 0$ we get an asymmetric equilibrium with an average volume of trade of 0.433 . In accordance with Claim 1 , the average volume of trade is larger than in the symmetric no transportation cost case (0.289). Thus the case of small transportation cost is different from the case of zero transportation cost. This is because in the low demand state all the buyers are residents of country 1 and the producer first market price is therefore lower for sellers in country 2. This is true for all $\tau>0$ and regardless of the magnitude of $\tau$. 


\section{CONCLUSIONS}

In the standard Walrasian analysis of economies with uncertain demand, trade starts only after all the uncertainty about demand is resolved and the auctioneer announces a price that guarantees the making of a sale. Here we studied the implication of a model that permits trade before the complete resolution of demand uncertainty and as a result the probability of making a sale may be less than unity. Our model is competitive in the sense that sellers take the price that they can sell to each batch that does arrive as given.

This model has been studied before but the application to international trade is new as far as I know. It is shown that the time of delivery makes a difference. In the delivery to stock case, we get dumping but no cross-hauling and no adverse welfare implications. Dumping occurs in this case because the probability of making a sale in the exporting country is lower and therefore the price must be higher to yield a given expected level of revenues per unit.

In the delivery to order case buyers are treated symmetrically. In this case, the stable demand (country 1) buyers may suffer from trade because in the high demand state some of them will not be able to make a buy at the low price and will be forced to buy at the high price. Since sellers in country 1 also suffer from trade, all agents in country 1 suffer from trade. This is a surprising result. On an abstract level it has to do with incompleteness of markets. But here it comes with a story and a rather realistic "friction" that allow for trade before the complete resolution of uncertainty. 
In the presence of transportation costs, the full integration delivery to order case yields interesting trade patterns. In the high demand state there is cross-hauling: Country 2 imports at the low price and exports at the high price. Note that cross-hauling occurs in two different "contingent commodities": Country 2 imports a good that will be delivered regardless of the state and exports a good that will be delivered only in the high demand state.

In the fully integrated case a symmetric equilibrium in which each seller supplies the same amount to each of the two hypothetical markets requires costless transportation. When transportation is costly the first market price that seller 1 gets is larger than the first market price that seller 2 gets because in the low demand state all the buyers are from country 1 . As a result seller 1 specializes in supplying to the first hypothetical market. Since it is shown (in Claim 1) that the symmetric equilibrium minimizes the expected volume of trade we have "too much" trade in the costly transportation case. 
APPENDIX TO THE DELIVERY TO STOCKS CASE: DUMPING WHEN THERE ARE ALWAYS TRANSACTIONS IN BOTH COUNTRIES

I now modify the example in section 2.1 and assume that in country 2 demand can have two strictly positive realizations. As before, the number of buyers who want to consume in country 1 is 1 . But the number of buyers who want to consume in country 2 is $1 / 2$ or 1 with equal probabilities. I assume the delivery to stock case.

Since the minimum number of buyers that will arrive in country 2 is $1 / 2$, we say that the first $1 / 2$ buyers that arrive buy in the first market. Additional $1 / 2$ buyers may arrive with probability $1 / 2$. If they arrive they buy in the second market. Thus, the first market in country 2 opens with probability 1 and serves $1 / 2$ buyers. The second market opens with probability $1 / 2$ and serves $1 / 2$ buyers. In country 1 there is only one market that opens with probability 1 .

I use the following notation: $x_{j i m}=$ supply to market $i$ in counrty $j$ by seller $m ; p_{j i}=$ the price in country $j$ market $i$.

Seller $m$ takes the prices $p_{j i}$ as given and chooses the quantities $\mathrm{x}_{j \mathrm{j}}$ to maximize his expected profits:

$$
p_{11} x_{11 m}+p_{21} x_{21 m}+(1 / 2) p_{22} x_{22 m}-(1 / 2)\left(x_{11 m}+x_{21 m}+x_{22 m}\right)^{2}-\tau \sum_{j \neq m} \sum_{i=1}^{2} x_{j i m}
$$

To write the first order conditions for (A1) I use the indicator function: $I(j \neq m)=1$ if $j \neq m$ and zero otherwise and $q_{j i}$ for the probability of making a sale in country $j$ market $i\left(q_{11}=1, q_{12}=0\right.$ and $\left.\mathrm{q}_{21}=1, \mathrm{q}_{22}=1 / 2\right)$. The first order conditions are: 


$$
x_{11 m}+x_{21 m}+x_{22 m}+\mathrm{I}(j \neq m) \tau \geq \mathrm{q}_{j i} \mathrm{p}_{j i} \text { with equality if } \mathrm{x}_{j \mathrm{~m}}>0
$$

Market clearing requires:

$$
x_{111}+x_{112}=\mathrm{D}\left(\mathrm{p}_{11}\right), \quad x_{211}+x_{212}=1 / 2 \mathrm{D}\left(\mathrm{p}_{21}\right), x_{221}+x_{222}=1 / 2 \mathrm{D}\left(\mathrm{p}_{21}\right) .
$$

Note that (A2) and (A3) is a system of nine equations in nine unknowns: $\mathrm{x}_{111}, \mathrm{x}_{112}, \mathrm{x}_{211}, \mathrm{x}_{212}, \mathrm{x}_{212}, \mathrm{x}_{222}, \mathrm{p}_{11}, \mathrm{p}_{21}, \mathrm{p}_{22}$.

Solution: I start by guessing a solution in which seller 2 supplies to both countries while seller 1 supplies only to his home country: $\mathrm{x}_{111}>0, \mathrm{x}_{112}>0, \mathrm{x}_{211}=0, \mathrm{x}_{212}>0, \mathrm{x}_{221}=0, \mathrm{x}_{222}>0$. As in the text, I use $P$ for the marginal cost of seller 2. Since under the proposed solution seller 2 supplies to both countries we must have:

$$
P=p_{21}=p_{11}-\tau=(1 / 2) p_{22}
$$

We can now express prices in each country in terms of $P$ :

$$
\mathrm{p}_{21}=\mathrm{P}, \mathrm{p}_{11}=\mathrm{P}+\tau \text { and } \mathrm{p}_{22}=2 \mathrm{P}
$$

To simplify, I use $\mathrm{x}=\mathrm{x}_{111}$ to denote the supply of seller 1 , $\mathrm{e}=\mathrm{x}_{112}$ to denote export of seller $2, \mathrm{k}_{1}=\mathrm{x}_{212}$ to denote the supply of seller 2 to the first market in his home country and $k_{2}=x_{222}$ to denote the supply of seller 2 to the second market in his home country. Using $\mathrm{C}(\mathrm{x})=(1 / 2) x^{2}$, leads to: 
(A6)

$$
C^{\prime}(x)=x=P+\tau \text { and } C^{\prime}\left(e+k_{1}+k_{2}\right)=e+k_{1}+k_{2}=P \text {. }
$$

The market clearing conditions can now be written as:

$$
\begin{gathered}
x+e=D(P+\tau)=1 /(P+\tau) \\
k_{1}=(1 / 2) D(P)=1 / 2 P, k_{2}=(1 / 2) D(2 P)=1 / 4 P .
\end{gathered}
$$

We now have five unknowns ( $\left.\mathrm{x}, \mathrm{e}, \mathrm{k}_{1}, \mathrm{k}_{2}, \mathrm{P}\right)$ with five equations (A6) and (A7). After some steps we get:

$$
2 P^{2}+3 P \tau+\tau^{2}-(3 \tau / 4 P)-7 / 4=0
$$

In Table A1 I solve (A8) for $P$ and then use (A5) - (A7) to get the other equilibrium magnitudes. This is done for two cases, $\tau=0$ and $\tau=0.1$. When $\tau=0$, the price in country 2 's first market is the same as the price in country 1 and production is the same in both countries. But country 2 exports the good because the average price in country 2 is higher and a smaller amount is required to satisfy demand at the higher average price.

Table A1

\begin{tabular}{|l|l|l|l|l|l|l|l|l|}
\hline$\tau$ & $\mathrm{P}$ & $\mathrm{p}_{11}$ & $\mathrm{p}_{21}$ & $\mathrm{p}_{22}$ & $\mathrm{x}$ & $\mathrm{e}$ & $\mathrm{k}_{1}$ & $\mathrm{k}_{2}$ \\
\hline 0 & 0.935 & 0.935 & 0.935 & 1.871 & 0.935 & 0.134 & 0.535 & 0.267 \\
\hline 0.1 & 0.883 & 0.983 & 0.883 & 1.766 & 0.983 & 0.034 & 0.566 & 0.283 \\
\hline
\end{tabular}


Note that in state 1 , the accusation of dumping cannot be supported because after transportation costs are taken into account country 2 exports at the same price that it sells at home. However in state 2 the accusation of dumping can be supported because the average selling price is greater than the export price net of transportation costs.

REFERENCES

Blonigen Bruce, A. "Evolving Discretionary Practices of US Antidumping Activity" mimeo, University of Oregon and NBER, April 2003.

Brander James A. "Intra-industry Trade in Identical Commodities" Journal of International Economics 11 (1981), 1 -14. And Paul Krugman. "A 'Reciprocal Dumping' Model of International Trade" Journal of International Economics 15 (1983), 313 - 321 . Butters, G. “Equilibrium Distribution of Sales and Advertising Prices" Review of Economic Studies 44:467-491 (1977).

Dana James D. Jr. "Advance-Purchase Discounts and Price Discrimination in Competitive Markets" Journal of Political Economy, Vol.106, Number 2, April 1998, 395-422.

Eden, Benjamin. "Marginal Cost Pricing When Spot Markets are Complete" Journal of Political Economy, Dec. 1990. Vol. 98, No.6,12931306 .

A Course in Monetary Economics: Sequential Trade, Money and Uncertainty, Blackwell, 2005.

Ethier, Wilfred J. "Dumping" The Journal of Political Economy, Vol. 90, Issue 3 (June 1982), 487-506.

Newbery, David, M.G. and Joseph E.Stiglitz. "Pareto Inferior Trade" The Review of Economic Studies, Vol. 51,1 (Jan. 1984), 1-12.

Prescott, Edward. C., "Efficiency of the Natural Rate" Journal of Political Economy, 83 (Dec. 1975): 1229-1236. 